\title{
A Framework for the Strategic Management of Science \& Technology Parks
}

\author{
Juliane Ribeiro ${ }^{1 *}$, Agnaldo Higuchi ${ }^{2}$, Marcelo Bronzo ${ }^{1}$, Ricardo Veiga ${ }^{1}$, Adriana de Faria ${ }^{3}$
}

\begin{abstract}
Science and technology parks (STPs) have been playing an increasingly influential role in the stimulation and growth of the knowledge economy. However, the spread of STPs faces relevant challenges, such as the development of robust performance management systems, able to demonstrate results and indicate improvement opportunities. Thereby, this paper proposes a theoretical model of performance management, which combines premises of the Service-Dominant Logic (S-D Logic), the Balanced Scorecard (BSC) and the General Hierarchical Model (GHM). Based on a multiple-case exploratory and qualitative study, relevant information about the strategic planning and management of these projects were extracted and paved the way for the construction of a performance hierarchical model composed of five perspectives, according to the BSC. Considering the outcomes, it is expected that the proposed model provide useful insights for the consolidation of a framework for the strategic management of science and technology parks.
\end{abstract}

Keywords: science and technology parks; service-dominant logic; balanced scorecard; general hierarchical model; performance management model.

Submitted: August $13^{\text {th }} 2016 /$ Approved: $\quad$ December $11^{\text {th }} 2016$

\section{Introduction}

There is an increase of evidence, in different economies, that science and technology parks (STPs) promote the construction of a new model of economic and social development, adhering to the knowledge economy. Based on the interaction between academia, business and government, these ventures seek to act as regional economic development catalysts, by facilitating the creation and development of new technology-based firms and technology transfer from universities to companies (Vilà \& Pagès, 2008).

In Brazil, the movement of STPs is recent and had its biggest boost only from the 2000s (Vedovello, Judice, \& Maculan, 2006). Data from the Ministry of Science, Technology and Innovation of the Brazilian government (MCTI, 2013) indicate the existence of 94 STPs initiatives in all five regions of the country, in different stages of development (planning, implementation and operation). As a whole, in the 28 ventures in operation, 939 companies are installed, generating more than 32.000 skilled jobs and significant impacts in terms of revenues and taxes.

Nevertheless, the dissemination of STPs in Brazil faces relevant challenges such as the scarcity of resources for expansion and improvement of infrastructure, the difficulty of attracting companies and to promote the alignment between institutional partners and the establishment of better management practices (Fundação CERTI, 2013). It is observed over the past few years the absence of more robust performance evaluation systems able to prove the achieved results, indicating opportunities for improvement and supporting the effectiveness of parks as a public policy instrument (Bigliardi, Dormio, Nosella, \& Petroni, 2006; Dabrowska, 2011; Monck \& Peters, 2009; MCTI, 2015; Phan, Siegel, \& Wright, 2005; Vedovello, Judice, \& Maculan, 2006).
Recently, some proposals have emerged for the elaboration of more detailed performance assessment systems that can be deployed relatively easily and are accepted by the main stakeholders (Andreevna, 2013; Dabrowska, 2011; Fernandes, 2014; Rodeiro-Pazos; Calvo-Babio, 2012). However, there is no consensus on what is a successful science and technology park and on what metrics should be employed to evaluate and compare different parks systematically (Dabrowska, 2011).

In order to contribute to the understanding of these issues, this paper suggests the use of the conceptual basis of the Service-Dominant Logic (Vargo \& Lusch, 2004), an innovative paradigm in the Marketing Theory for analysis of exchange between economic and social actors, as a theoretical support for the understanding of phenomena and processes of science and technology parks. Specifically, the article aims to reflect on the actions of the actors involved in these ecosystems, especially universities, business and government, with regard to the integration of resources and value cocreation.

Aiming to consubstantiate the analyzes and to contribute to the evaluation theme of STPs performance, it was developed a theoretical model based on the Balanced Scorecard (Kaplan \& Norton, 1997, $2000,2004)$ and in the premises for the construction of scales and models elaborated on the General Hierarchical Model (Mowen \& Voss, 2008). The proposed model has as its central feature the expansion of the assessment results focus to the performance management view. Thus, development is aimed at identifying strategic resources for value cocreation in STPs, as well as the understanding of the relationship between these resources and the best known performance indicators of these innovation environments.

(1) Universidade Federal de Minas Gerais, UFMG

(2) Universidade Federal dos Vales do Jequitinhonha e Mucuri, UFVLM

(3) Universidade Federal de Viçosa, UFV

*Corresponding author: juliane.ribeiro@ifmg.edu.br

ISSN: 0718-2724. (http://jotmi.org)

Journal of Technology Management \& Innovation @ Universidad Alberto Hurtado, Facultad de Economía y Negocios. 
Initially, the work presents the theoretical background, which describes the fundamentals of the Service-Dominant Logic (S-D logic), science and technology parks, the Balanced Scorecard performance management model (BSC) and performance assessment approaches in STPs. The literature review is concluded with a discussion of the relationship between the S-D logic and the BSC and the explanatory power of the S-D logic against the phenomenon of science and technology parks, especially about value cocreation and resources integration practices. Then it is presented the research method, the proposed hypothetical-conceptual model and the suggestion of indicators to operationalize the constructs. At the end of work, considerations are made on the issues discussed, indicating the limits of this research and suggestions for future studies on the subject.

\section{The Service-Dominant Logic}

The Service-Dominant Logic (S-D logic) is a proposal for a paradigm change, from the dominant current "Goods-Dominant Logic" (G-D logic) for a Service-Dominant Logic, in which the term Service means the application of competences (knowledge and skills) for the benefit of another party and/or yourself (Lusch \& Vargo, 2006). According to the G-D logic, values are constantly created and destroyed following the principle set out in the diagram of Figure 1 (Bettencourt, Lusch, \& Vargo, 2014):

Figure 1. Diagram of value creation in the Goods-Dominant Logic. Data from Bettencourt, Lusch e Vargo (2014).

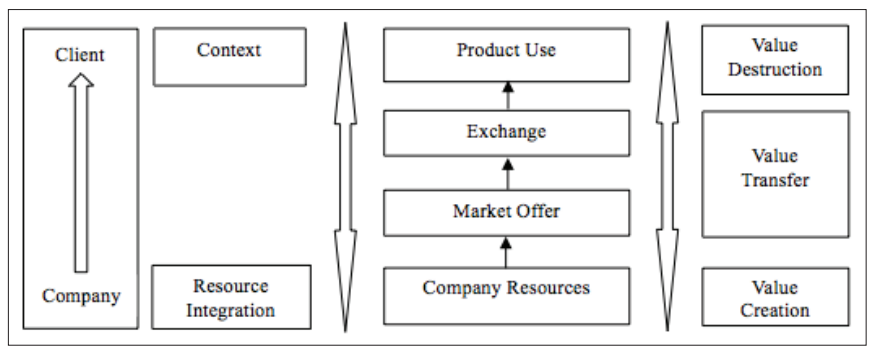

For Lusch and Vargo (2006), the S-D logic rejects the premise that only the firm can create value at the time of production of goods or services. According to the authors, any product, tangible or not, is only part of the provision of a service, that is, what is actually being exchanged is always service by service. The exchange value emerges in the use and it is cocreated by the actors involved in a service ecosystem, from integrated resources. In S-D logic values can be constantly cocreated, following the principle set out in the diagram of Figure 2:

Figure 2. Diagram of value creation in the Service-Dominant Logic. Data from Bettencourt, Lusch e Vargo (2014).

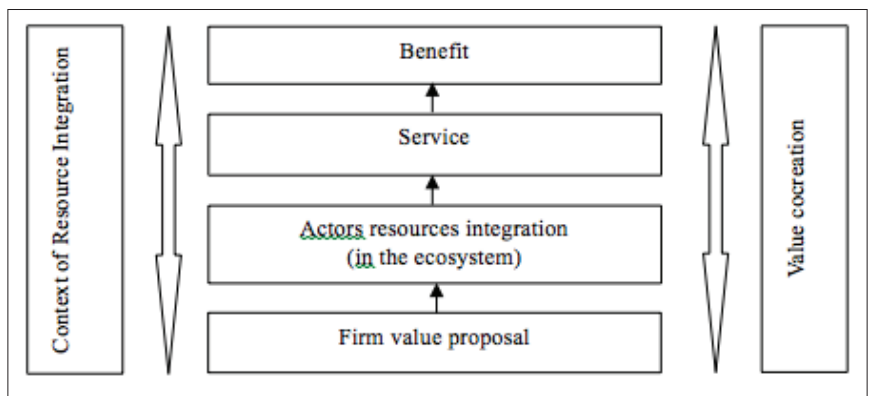

The theoretical framework from the S-D logic can be presented through its eleven foundational premises, five of which are considered more basic or axioms, as shown in Table 1.

Table 1. Axioms and foundational premises of the Service-Dominant Logic. Data from Vargo and Lusch (2016, p. 8).

A1 (FP 1) Service is the fundamental basis of exchange.

FP 2 Indirect exchange masks the fundamental basis of exchange.

FP 3 Goods are distribution mechanisms for service provision.

FP 4 Operant resources are the fundamental source of strategic benefit.

FP 5 All economies are service economies.

A2 (FP 6) Value is cocreacted by multiple actors, always including the beneficiary.

FP 7 Actors cannot deliver value but can participate in the creation and offering of value propositions.

FP 8 A service-centered view is inherently beneficiary oriented and relational.

A3 (FP 9) All economic and social actors are resource integrators.

A4(FP 10) Value is always uniquely and phenomenologically determined by the beneficiary.

A5 (FP 11) Value cocreation is coordinated through actor-generated institutions and institutional arrangements.

Notes: Abbreviations: A = Axiom; FP = Foundational Premise. In bold, the axioms.

These fundamental premises provide a framework to review and possibly increase the knowledge of the exchange process and its role in society (Lusch \& Vargo, 2006). Essentially, S-D logic provides a more holistic, dynamic and realistic perspective of value creation, through exchange, among a wider, more comprehensive (than firm and customer) configuration of actors (Vargo \& Lusch, 2016).

In S-D logic, the traditional firm-customer view must be overcome for a systemic approach of networks of actors interacting in a service ecosystem, in which all actors integrate resources and engage in service exchange, in the process of cocreating value (Vargo \& Lusch, 2016). It is thus necessary to conceptualize important elements from the lexicon of S-D logic, such as ecosystem, value and resource. This is the content developed in the following subsections.

\section{The service ecosystem}

The service ecosystem, in the S-D logic, is defined as a system of direct and indirect exchange relationships between the actors involved. It is then necessary to abandon the producer-consumer dyad and to adopt the premise that in service exchange, resource-integrating actors "are connected by shared institutional logics and mutual value creation" (Lusch \& Vargo, 2014). So, in the service ecosystem, all participants, directly and indirectly involved in the exchange are actors, and there is not, at first, separation between suppliers and consumers. 
The ecosystem term is chosen to indicate a dynamic adaptation of the system. The systems are dynamically self-adjusting, while acting and reconfiguring the resource integration process and value creation aiming to increase the chance of survival and the ecosystem's viability. The system's view differs from the network view by the fact that in the system, at each resource integration, service provision and value creation, there is a change to some extent of the context for the next iteration and determination of value creation (Wieland, Polese, Vargo, \& Lusch, 2012).

Within the service ecosystem actors perform amongst themselves exchanges that can be of three basic types: strict, general and complex (Lusch \& Vargo, 2014). The type of restricted exchange corresponds to the dyad in which an actor "A" exchanges service with an actor "B. In the type of general exchange, at least three actors perform indirect exchanges. The complex changes, in turn, are characterized by the presence of at least three actors, connected by a network of relationships in which each actor involves in a direct exchange at least once. This service exchanges allows the cocreation of value by the actors, as discussed below.

\section{Value and value propositions}

In the traditional view from the Goods Dominant Logic, value is created only by the producer organization of goods or services, leaving the client to consume this value function (Bettencourt, Lusch, \& Vargo, 2014). In the Service Dominant Logic, however, the organization, with its resources, offers a value proposition to be exchanged with a customer. The integration of resources from the organization and other actors (government, family and other organizations) brings benefits to the consumer, which then becomes a beneficiary who cocreates value.

In this sense, the cocreated value can be measured as a perceived benefit. This value needs to be analyzed within a specific context of interactions and social structures. These social structures, in turn, are the ones that make it available to actors both the rules and the resources that can be employed in the activities and interactions. Following, it is presented the concept of resource in the S-D logic.

\section{Resources and integration of resources}

The integration of resources refers to organizations, families and individuals that transform micro specialized competences in complex services demanded in the market, which performs specific functions of the service system to a beneficiary or specific actor in the system (Peters et al., 2014). It is noticed that the integration of resources is not possible if these are limited to physical materials, such as raw materials. In S-D logic resources are the tangible and intangible entities available used to create value, being the service the result of the application of operant resources such as knowledge and skills on operand or tangible resources.

Another important concept related to resources is the density. Briefly, density is a measure of the amount of information, knowledge and other resources accessible to the actor at a given time and place, to solve a certain problem. To create or increase density in a particular situation, companies can separate and recombine resources. The higher the density, the higher the integration of resources and therefore the greater the potential value that can be cocreated (Lusch \& Vargo, 2014).

Either service and value cocreation result from the resource integration (operant and operand) of multiple actors, which requires communication and coordination. The cocreation of value is necessarily a joint activity, which depends on the establishment of mutual understanding (instructions) so that different entities achieve common goals. On the other hand, mutual understanding is also cocreated because it is achieved through shared institutional logics, such as experiences, context and information, as well as other shared resources as a language specifically created by a group that facilitates the connection between its members (Maglio \& Spohrer, 2008).

This proposed change in the concepts of value, value cocreation, resources, and how to see the relationships between the actors in the market, expanding the relationships pertaining to the dyad businessconsumer to relationships in a broader service ecosystem, provides a new perspective to analyze more complex interaction phenomena as, for example, social and technological phenomena involved in the science parks ecosystems.

\section{Science and technology parks}

The concept of a science park originated in the United States in the 1950s, in Stanford, California. Based on the co-evolution of science and technology, science parks aim to promote technical infrastructure, logistics and administration to help small businesses develop their products, increase their competitiveness, promote technology transfer and the creation of an environment conducive to innovation (Bakouros, Mardas, \& Varsakelis, 2002; Phillimore, 1999).

The importance of science parks can be seen by its spread in developed and developing countries and the emergence of a growing research literature, especially from the 1980s (Fiates, 2014; Phan, Siegel $\&$ Wright, 2005). The interest in these innovative environments, based on the Triple Helix model, has increased as government, academic and business actors realize its potential as a catalyst for innovative entrepreneurship and technological and socio-economic development.

In Brazil, according to the Brazilian Association of Science Parks and Business Incubators (ANPROTEC) a science park is:

a productive industrial complex and scientific-technological base services, planned, with formal character, concentrated and cooperative, which aggregates companies whose production is based on technological research developed in $R \& D$ centers linked to the park. It is a promoter of the enterprise culture of innovation, competitiveness, increasing business skills, based on the transfer of knowledge and technology, with the aim of increasing the production of wealth of a region (ANPROTEC, 2015, s/p). 
That way it is observed that a science park is a planned and cooperative space, in which technology based companies interact with themselves and with educational, research and development institutions. It is up to the park the offering of value-added services to promote the culture of innovation, competitiveness and increased business capacities, which will foster wealth creation in the region.
In a more systematic approach, the main actors involved in science parks, their contributions and the expected results by these stakeholders can be seen in Table 2 .

Table 2. Science Parks: key stakeholders, contributions and expected results. Adapted from Vedovello, Judice and Maculan (2006).

\begin{tabular}{|c|c|c|}
\hline STAKEHOLDERS & KEY CONTRIBUTIONS & EXPECTED RESULTS \\
\hline Universities and research institutes & $\begin{array}{l}\text { - Scientific basis: human capital, technology } \\
\text { infrastructure and organizational capital. } \\
\text { - Capacity to attract companies and talents. }\end{array}$ & $\begin{array}{l}\text { - Commercializing academic research results expanding } \\
\text { the sources of financial resources. } \\
\text { - Expand the institutional mission. } \\
\text { - Expand the labor market for researchers and students. }\end{array}$ \\
\hline $\begin{array}{l}\text { Entrepreneurs and academics } \\
\text { entrepreneurs }\end{array}$ & $\begin{array}{l}\text { - Entrepreneurial culture, technical and market } \\
\text { knowledge. }\end{array}$ & $\begin{array}{l}\text { - Use results of academic activities and research in order } \\
\text { to boost their own R\&D business. } \\
\text { - Boost financial returns. } \\
\text { - To access qualified human resources. }\end{array}$ \\
\hline Financial agents and venture capitalists & $\begin{array}{l}\text { - Availability of financing and technical and } \\
\text { managerial support to companies. }\end{array}$ & $\begin{array}{l}\text { - Investing in new technology based companies with high } \\
\text { and fast economic growth potential and financial returns. }\end{array}$ \\
\hline
\end{tabular}

Considering the context presented, we can see that the proposition of an evaluation and performance management mechanism in these ecosystems is a complex task due to the variety of actors involved, expectations and value propositions. In this sense, the use of a multidimensional model of performance, such as the Balanced Scorecard, adapted to the Science Parks context, can contribute to the understanding of the integration of resources and cocreation of value in these ventures.

\section{Balanced Scorecard}

In the early 1990s, the belief that the methods traditionally used to measure business performance were becoming obsolete because they consider only accounting and financial indicators, led to the creation of a new management tool called the Balanced Scorecard (BSC). As a differential, the BSC promoted and integrated important aspects related to value creation for organizations, such as human capital, the critical internal processes and the value proposition to customers or target audience, which would be intrinsically related to the achievement of financial results and fulfillment mission.

The Balanced Scorecard name (Balanced Measurements System) was chosen because the model reflected the balance between short and long term objectives, between financial and nonfinancial, among trend indicators and results and between internal and external perspectives of performance. This way the BSC proposes the integration of objectives, indicators, targets and initiatives in four interrelated categories of performance: financial, customer, internal processes, and learning and growth (Kaplan \& Norton, 1997).

The financial perspective is responsible for defining the expected financial performance of the strategy and to provide the main targets for the objectives and measures of all other perspectives of the scorecard. Financial performance measures tangible results of the strategy, which show whether the organization is heading for success. Two main themes guided this perspective: revenue growth and increased productivity (Kaplan \& Norton, 2004).

According to the logic of the BSC, the improved financial performance is closely related to the success in meeting the desires and target customer needs. Thus, it is necessary to carefully establish the organization's value proposition, which will clarify the context for intangible assets and internal processes to create value. The success of the customer's perspective can be measured by indicators of results such as satisfaction, retention and growth of success with customers.

While the financial and client perspectives describe the expected results of the implementation of the strategy (constitute external sides of the performance), the size of internal processes identifies the critical few processes that must exert the greatest impact on strategy (Kaplan \& Norton, 2004, p. 32). These are the processes that will create and fulfill the value proposition for customers and indicate improvement trends that will impact on the target audience and financial results. 
On the basis of the BSC, the learning and growth perspective is responsible for defining the most important intangible assets for strategy. The objectives in this perspective identify which jobs (human capital), systems (information capital) and type of climate (organizational capital) are needed to support the internal processes of value creation. These assets must be coherently connected with each other and aligned to the critical internal processes (Kaplan \& Norton, 2004). Furthermore, "the improvements in the results of learning and growth are trend indicators for the internal processes, customers and financial performance" (Kaplan \& Norton, 2004, p. 7).

The four perspectives mentioned, present in most applications of the BSC, can be complemented by other dimensions, as long as these are considered strategic in the organization's context (Kaplan \& Norton, 1997). Thus, public sector institutions and non-profit organizations also make use of the BSC. The difference is that in this case, the ultimate criteria of success is not financial performance, or the creation of sustainable value for shareholders, but the performance in fulfilling the mission obtained through the creation of sustainable value for two interest groups: contributors and beneficiaries (Kaplan \& Norton, 2000; 2004).

Throughout research and applications, the BSC has evolved from an optimized performance measurement system for a strategic management system, capable of promoting alignment and focus. Its use has been encouraging the development of principles of action in organizations such as the mobilization of change through executive leadership, the conversion of strategy to a continuous process, the transformation of strategy task of all organizational stakeholders, the organization's alignment to the strategy and translation of strategy into operational terms (Kaplan \& Norton, 2000).

The BSC has also been improved and complemented by a management tool called "Strategic Map", used to describe strategy through goals interconnected in cause and effect relationships in the four perspectives (Kaplan \& Norton, 2004). The strategy map provides further details about each perspective, improving the clarity and focus of the strategy.

Recently, the issue of evaluating science parks' performance, which is typically based on the comparison of results from technology-based companies located inside and outside these environments or in the monitoring of innovation and financial outcomes of parks, is being reinvigorated by more robust techniques based in consolidated references, able to bring new elements for a more consistent analysis of science parks' performance.

\section{Performance Evaluation of Science and Technology Parks}

Performance evaluation of science and technology parks is becoming an increasingly relevant issue for the actors involved (Bigliardi et al., 2006; Dabrowska, 2011; Rodeiro-Pazos \& Calvo-Babio, 2012), as there is a real demand for transparency and effective results in terms of local development, innovation and revenue for companies (Bigliardi et al., 2006; Monck \& Peters, 2009).
According to Fernandes (2014), the need to assess the effectiveness of science parks arose due to the expansion of the concept and the creation of new parks. It can be understood as a result of the maturing of the mechanism as a promotional policy to technological entrepreneurship. Indeed, the assessment shows stakeholders and managers improvement opportunities for the future.

In fact, the importance of this issue was highlighted in the study of MCTI (2015), which involved the development of suggestions for the improvement of support policies for science parks in the country. Among these, it can be included the definition of framework criteria for different stages of development (planning, installation and operation) and performance indicators for the investment of public resources; the development of services and support mechanisms to promote the interaction between innovation actors (companies and universities); and the development of a performance evaluation system for science and technology parks.

Typically, the performance of these ventures has been analyzed by comparing results of technology-based companies within parks versus outside parks. Several studies investigated the existence of statistically significant differences in indicators such as number of jobs created, sales volume, $R \& D$ results, new products and/or services and business survival rate (Dabrowska, 2011; Monck \& Peters, 2009).

Some studies showed that companies located in parks have better performance of research and innovation and greater propensity to develop joint projects with universities (Fukugawa, 2006; Siegel, Westhead \& Wright, 2003; Squicciarini, 2008). There is also evidence of positive impacts of science parks in the growth and image of the universities involved, with highest number of publications, patents and technology transfer and better allocation of graduated (Link \& Scott, 2003). However, in general, the evidence of superior performance of tenant companies in parks compared to companies outside the parks are assessed as weak (Dabrowska, 2011; Monck \& Peters, 2009).

At the same time, another common way to measure the performance of science and technology parks is the monitoring of general information, such as the number of tenant companies, the occupied area, the jobs created (Dabrowska, 2011), the level and type of investments made, the tenant company's revenues, the number of startups, patents and new products created (Bigliardi et al., 2006; Dabrowska, 2011; Rodeiro-Pazos e Calvo-Babio, 2012).

Even though these evaluations provide important information on the results achieved, they are limited as they do not explain how to improve science parks' performance. Therefore, there is a need to develop more systematic approaches, supported by consolidated analytical frameworks, that can deal with the resources and expectations of the actors involved and be applied in a practical way by managers and stakeholders concerned with science parks.

Recent researches have used the Balanced Scorecard as a theoretical and methodological framework to propose a more consistent system for performance management in science parks (Andreevna, 2013; Da- 
browska, 2011; Rodeiro-Pazos \& Calvo-Babio, 2012). In these studies, contributions are pointed at the subject, especially in suggesting lines of analysis and indicators for measuring the effectiveness of these ventures. However, a common limitation is the lack of a methodology to integrate the dimensions and indicators in cause and effect relationships, in order to highlight the most strategic resources and the connections underlying value cocreation in science and technology parks.

\section{Methods}

This research can be characterized as exploratory and qualitative. According to Gil (2006), exploratory researches have as its principle to develop, clarify and modify concepts and ideas, through the development of more precise problems or searchable hypotheses for further studies. Given that the proposed work is rarely studied in the literature, there was an exploratory research to deal with aspects of a performance management model of science parks, considering key success factors, services and results of these ventures.

The qualitative character of the research is due to the emphasis given to the processes and meanings (Sale, Lohfeld, \& Brazil, 2002). In this sense, the multicases study was used as a methodological strategy. According to Yin (2005), the case study applies as an empirical investigation of a contemporary phenomenon within its real-life context, especially when the boundaries between phenomenon and context are not clearly defined. For Gil (2006), one of the purposes of the case study is to explain the causal variables of a given phenomenon in very complex situations that do not allow the use of surveys and experiments. In fact, the multicases study allowed obtaining a wider knowledge of the planning, management and performance of science parks, which contributed to the proposition of a theoretical model grounded in the reality of these environments.

For this research, there was collected primary and secondary data. Initially, the literature review on Service-Dominant Logic, Science and Technology Parks and Balanced Scorecard provided material to elaborate semi-structured questions covering planning and strategic performance management of STPs. After the elaboration, ten semistructured interviews were made with strategic and operational level managers of three STPs in operation in Brazil: tecnoPARQ (Viçosa - MG), BH-TEC (Belo Horizonte - MG), and Sapiens Parque (Florianópolis - $\mathrm{SC})$.

These parks are in different stages of maturity and regional contexts, allowing a broader spectrum of analysis of management practices, important for the construction of reference models. Even though they are all in operation, the tecnoPARQ and BH-TEC are younger, with about five years of activity. Sapiens Parque, on the other hand, is a more mature venture with about ten years of operation. In addition, the BH-TEC and Sapiens Parque are located in large urban centers (capitals), while tecnoPARQ has the challenge of being successful out of large cities, in the up-country.

For the analysis of data obtained through the interviews, direct observation and analysis of institutional documents, content analysis technique was used, more specifically thematic analysis. According to Bardin (2000, p. 106), "the answers to open questions, [...] can be and are, often, analyzed with the theme as a basis". In this sense, related information from the interviews were grouped and four thematic categories have been formulated, addressing: (i) critical success factors; (ii) service portfolio; (iii) performance indicators, positioning and strategy; and (iv) strategic objectives of the parks. It followed this analysis the proposition of the research conceptual model, the development of hypotheses and the constructs' operational definition.

Following, it is presented the discussion that led to the research hypotheses, the suggested conceptual model and the indicators to measure the constructs.

\section{Discussion of results}

\section{The Service-Dominant Logic, the Balanced Scorecard and Science and Technology Parks}

In this research, both the Service Dominant Logic and the Balanced Scorecard were used for the analysis of resource integration and value cocreation in science and technology parks. Service-Dominant logic approach is holistic and integrative, and its key concepts, such as service, actor, resource, value and ecosystem, are consistent with the context of science parks. Besides, the BSC is recognized as an important strategic management system, able to associate objectives and performance indicators and to provide organizational alignment and focus. In addition, both S-D logic and BSC emphasize the relevance of intangible assets or operant resources (such as knowledge, skills and competences) for value creation. Essentially, this research assumes that these theories can be used together for the analysis of the science park ecosystem, supporting the proposal of a performance management model adapted for these innovation environments.

According to S-D logic, strategy success depends on the company's ability to effectively develop collaborative relationships which will promote the integration of resources and the creation of new resources. By definition, science parks must work to enhance institutional cooperation between university-industry-government (Giugliani, Selig, \& Santos, 2012). Therefore, the proximity, the exchange of experiences and complementarity of competences between these actors (resource integration) are fundamental to the generation of synergies and consistent results.

The adoption of S-D logic also involves assessing the performance of science parks based on cocreated value by government actors, universities and companies. The direct and indirect benefits created by these ventures serve the different stakeholders and are represented by employment opportunities, increasing number of patents and technology transfers and the strengthening of entrepreneurship (Dabrowska, 2011). Thus, the cocreated value would result of combined efforts from different stakeholders and from the effective integration of resources.

Taking up the five basic axioms of S-D logic, it is possible to relate them to the context of science parks in the following way: 
A1 - service is the fundamental basis of exchange: based on the definition of ANPROTEC (2015, sp), it can be inferred that the park management service is "to promote the culture of innovation, competitiveness, increasing business skills, based on the transfer of knowledge and technology". In other words, the main benefit generated by science parks to tenant companies consists in providing a planned and cooperative environment with high value-added services that facilitate the flow of knowledge, technology and resources between actors and lead to the development of new products and services. But the service offered by tenant companies is the generation of positive externalities such as jobs, new products, revenues and encouragement for the innovative entrepreneurship culture. The government, by its turn, offers the service in the form of political/institutional support, through investment, financing, innovation policy and regulatory framework. And universities provide the service in the form of intellectual capital, knowledge and research and development infrastructure.

A2 - Value is cocreacted by multiple actors, always including the beneficiary: in this work's view, the actors involved are the academy (universities), the government, the financial agents, the community around the park and the entrepreneurs (companies). In this ecosystem, one actor only can cocreate value (receive benefit) if different kinds of resources (operand and operant) are available: entrepreneurial culture, public policies supporting technological innovation, financial resources and facilities. If the beneficiary is represented by the tenant companies, the benefit received is the environment provided to accelerate technological innovation or the introduction of solutions, new products or services on the market successfully (Fiates, 2014). Tenant companies cocreate value in its operation when they integrate their knowledge resources with other actors, creating benefits as community socioeconomic development.

A3 - All economic and social actors are resource integrators: all actors involved in the innovation processes in science parks are resource holders (operant and operand). The government, for example, has resources for funding; the universities, resources in the form of knowledge and infrastructure; and businesses in the form of entrepreneurship and innovation. All these actors, while interacting, integrate their resources maximized in a higher density to increase the viability of the ecosystem.

A4 - Value is always uniquely and phenomenologically determined by the beneficiary: in the case of this study, the focus beneficiary is the tenant companies. Therefore, the model will seek to measure the most important benefits for these players, that is, the value cocreated. The same benefits can generate different values for different actors, as well as each tenant company can realize a different value for each resource to it offered.

A5 - Value cocreation is coordinated through actor-generated institutions and institutional arrangements: as described earlier, value cocreation depends on the establishment of mutual understanding and instructions to guide different entities towards common goals. This mutual understanding is improved if institutional logics, such as information, and other shared resources that facilitates the connection between its members (Maglio \& Spohrer, 2008) are available. In this study, these connections facilitators are represented by factors such as the level of cooperation culture, entrepreneurial culture and encouraging entrepreneurship policies.

As seen above, each actor in the science and technology park ecosystem can cocreate different values, since the integrated resources differ from actor to actor. In this study, these values will be expressed in the definition and implementation of the model constructs. Another important point concerning this research is the assumption that the key success factors of science parks and the best known performance indicators of these ventures are also represented in the conceptual model.

\section{Interviews analysis and the proposal of an analytical model}

The thematic analysis of the interviews revealed what science parks managers consider the main goal of the parks: to increase economic development. All interviewers agreed at this point. They also agreed that this development depends on the availability of operand resources such as spaces, facilities and financial credit. Operant resources are indispensable too, such as management capacity of the science park team, public policies to encourage entrepreneurship, human capital and entrepreneurial culture of the tenant companies.

In order to overcome barriers and achieve this context of development, each park interviewed adopted different strategies. They are different due to the different maturity stages in which they are. The relative geographical position (central/peripheral) impacts too, along with the availability of resources coming from government and universities. The parks' strategies for development involve aspects such as the attraction of startups, big companies' $R \& D$ departments and anchor business, partnerships within the science parks net and the search for public and private financial resources.

In fact, the interviews have shown that the strategies adopted aim to overcome difficulties concerning lack of financial, human and material resources, and this search for resources has left no room to prospect a path to increase the future performance of the park. For instance, in the BH-TEC the challenge now is to raise financial resources to build another facility, to admit new companies. And in tecnoParq, most of the human resources are composed by fellows' trainees who stay for a short time and cause a high turnover.

On the other hand, even with all the restrictions, all respondents agreed that the parks have brought benefits to the tenant companies and the community around the park. The companies receive services (in the SD-L sense) like management support and commercial advice and when integrate their resources (as knowledge and technology) the value is cocreated. In the community case, the benefits come as employment and income. The University (in the cases where its resources are properly integrated) receives the benefit of increase and diffusion of knowledge. 
From the Service Dominant Logic point of view, the interviews reveal a lack of resource density. The relationship between government and academy and between academy and Science Park, and Science Park and government seems to be not properly set to an optimum result. So, an analytical model is proposed to help to analyze and propose solutions to the problem identified. The analytical model that integrates key success factors, services and results of science parks in the theoretical framework of the S-D logic is shown in Figure 3.

According to the proposed analytical model, the benefits are generated by the integration of resources of the actors that in this process are influenced by several factors, such as the government's public policies, cooperation of universities, entrepreneurial local culture. The park management also impacts the value cocreated, because it is directly linked to the coordination of resources towards higher density. According to the above, the S-D logic approach is valid to the understanding of relationships and parks phenomena. From this analytical model, based on the assumptions of S-D logic, the science parks literature and the context of the science parks interviewed, it is suggested a hypothetical conceptual model for measuring the relationships among the strategic resources of the actors, the technological, scientific and socioeconomic progress brought by these ventures (benefits), and the value cocreated for tenant companies, universities and government.

Figure 3. Analytical model of value cocreation in the ecosystem of the science park in the perspective of S-D logic. Data based on Bettencourt, Lusch and Vargo (2014).

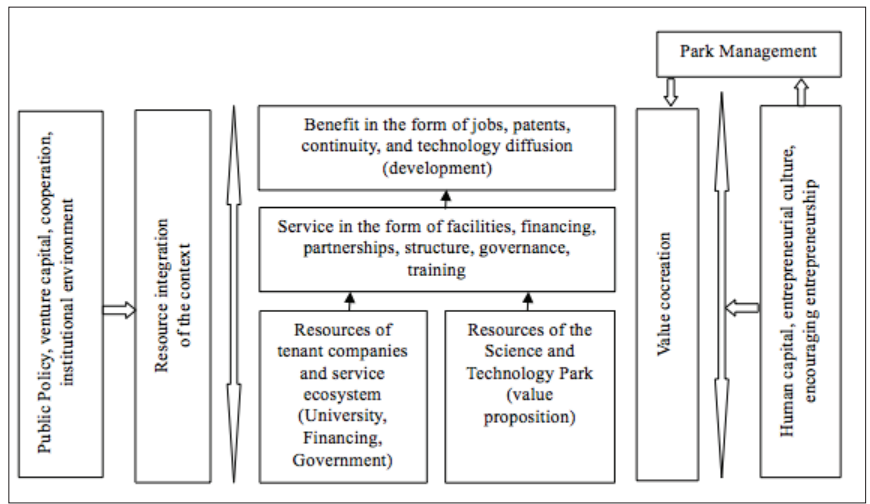

Once defined the elements involved in the value cocreation process of the science parks in Brazil, the next step is to create a way to quantify the relation between each of these elements. This quantification demands a conceptual model, research hypothesis, scales and a framework to analyze the effect and significance (existence) of the relationships. In the following topic these aspects are addressed.

\section{Conceptual model, research hypothesis and scales}

Based on a review of literature on S-D logic, BSC and science and technology parks, as well as the analysis of the multicases study, a hypothetical-conceptual model for performance management of science and technology parks was proposed. The model consists of an adaptation of the BSC management tool to the context of strategic management of parks. Considering the theoretical proposal of S-D logic, developed in this work, the main actors present in this ecosystem are represented: park management, tenant companies, universities and government. Each of them has different resources that must be assessed. In order to perform these assessments, some dimensions are suggested.

The performance of the team management and the government, with regard to the provision of support bases for the performance of companies, is directly covered in the dimensions of Learning \& Growth and Internal Processes. The value proposition cocreated by these stakeholders will be assessed from the perspective of Tenant Companies, defined as the focal actors in this model. In the Science, Technology and Innovation dimension, the intensity and the universitycompany relationship results are discussed. Finally, a more holistic contribution of the park to the region where it operates is handled through the dimension of Sustainable Socioeconomic Development. Therefore, the perspectives/constructs and their concepts are synthetically presented in Table 3 .

Table 3. Model dimensions

\begin{tabular}{|c|c|}
\hline Perspective / Construct & Concept \\
\hline Learning \& Growth & $\begin{array}{l}\text { It refers to the critical success factors or } \\
\text { to the intangible and tangible assets (op- } \\
\text { erant and operand resources) required } \\
\text { for the venture's success. }\end{array}$ \\
\hline Internal Processes & $\begin{array}{l}\text { Refers to activities related to the orga- } \\
\text { nization, the coordination and the most } \\
\text { relevant services provided by the park, } \\
\text { aiming at the growth of businesses and } \\
\text { the organization itself. }\end{array}$ \\
\hline Tenant Companies & $\begin{array}{l}\text { It refers to the proposed park value for } \\
\text { tenant companies. It consists of evaluat- } \\
\text { ing the performance of the park as a fa- } \\
\text { cilitator of technological innovation and } \\
\text { business development, as well as its ef- } \\
\text { fectiveness in providing value solutions } \\
\text { for companies. }\end{array}$ \\
\hline $\begin{array}{c}\text { Science, Technology \& Inno- } \\
\text { vation }\end{array}$ & $\begin{array}{l}\text { It refers to the work of the park as a pro- } \\
\text { moter of the university-business rela- } \\
\text { tionship, aiming results of scientific and } \\
\text { technological development. }\end{array}$ \\
\hline $\begin{array}{c}\text { Sustainable Socioeconomic } \\
\text { Development }\end{array}$ & $\begin{array}{l}\text { It refers to more holistic results of the } \\
\text { project in the region where it is located, } \\
\text { contemplating benefits of socioeconom- } \\
\text { ic and environmental nature. }\end{array}$ \\
\hline
\end{tabular}

For the construction of the hypothetical conceptual model, by its turn, the General Hierarchical Model (GHM), proposed by Mowen and Voss (2008), was used as a reference. This model provides a framework in which the constructs are distinguished not only by conceptual differences but also by level of abstraction. In a hierarchical model, the constructs have prior relationships and are fully interrelated. Thus, applying the GHM in the proposed model based on the BSC, the process starts from more intangible constructs such as learning and growth, to reach more tangible constructs such as science, technology, innovation and sustainable socioeconomic results. The Hypothetical Conceptual Model is shown in Figure 4. 
Figure 4. Hypothetical-conceptual model proposed, based on BSC

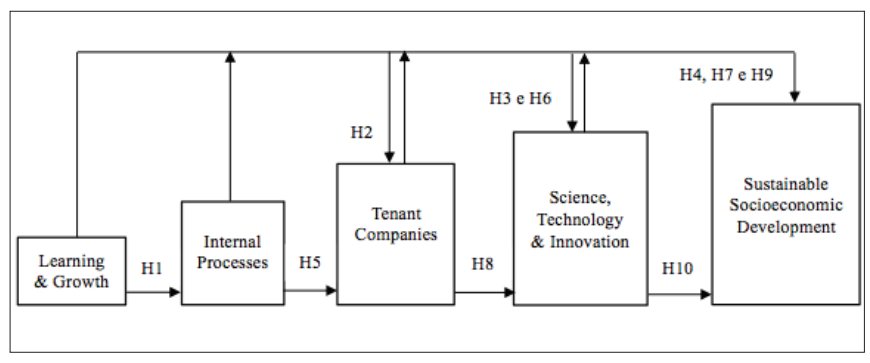

Thus, the research hypotheses arising from the model were constructed, as shown in Table 4 . These hypotheses will be tested:

Table 4. Research model hypotheses

\begin{tabular}{|l|l|}
\hline H1 & $\begin{array}{l}\text { The perspective of Learning and Growth has a positive effect on } \\
\text { the perspective of Internal Processes. }\end{array}$ \\
\hline H2 & $\begin{array}{l}\text { The perspective of Learning and Growth has a positive effect on } \\
\text { the perspective of Tenant Companies. }\end{array}$ \\
\hline H3 & $\begin{array}{l}\text { The perspective of Learning and Growth has a positive effect on } \\
\text { the perspective of Science, Technology and Innovation. }\end{array}$ \\
\hline H4 & $\begin{array}{l}\text { The perspective of Learning and Growth has a positive effect on } \\
\text { the perspective of Sustainable Socioeconomic Development. }\end{array}$ \\
\hline H5 & $\begin{array}{l}\text { The perspective of Internal Processes has a positive effect on the } \\
\text { perspective of Tenant Companies. }\end{array}$ \\
\hline H6 & $\begin{array}{l}\text { The perspective of Internal Processes has a positive effect on the } \\
\text { perspective of Science, Technology and Innovation. }\end{array}$ \\
\hline H7 & $\begin{array}{l}\text { The perspective of Internal Processes has a positive effect on the } \\
\text { perspective of Sustainable Socioeconomic Development. }\end{array}$ \\
\hline H8 & $\begin{array}{l}\text { The perspective of Tenant Companies has a positive effect on the } \\
\text { perspective of Science, Technology and Innovation. }\end{array}$ \\
\hline H9 & $\begin{array}{l}\text { The perspective of Tenant Companies has a positive effect on the } \\
\text { perspective of Sustainable Socioeconomic Development. }\end{array}$ \\
\hline H10 & $\begin{array}{l}\text { The perspective of Science, Technology and Innovation has a pos- } \\
\text { itive effect on the perspective of Sustainable Socioeconomic De- } \\
\text { velopment. }\end{array}$ \\
\hline
\end{tabular}

Regarding to the operationalization of the constructs, the indicators need to provide consistency with both the BSC and the context of science and technology parks. In this sense, the following considerations are presented:

- Learning \& Growth: reflecting the emphasis on human capital, technological infrastructure and information and organizational capital, suggested by the BSC, it is intended to approach key success factors such as the ability to attract and retain talent, the work in strategic and effective networks, the quality of the scientific and technologic basis, the entrepreneurial culture of the region, among others.

- Internal Processes: with reference to the central themes presented in the Strategic Map (resulting tool from BSC), it is suggested to analyze the main value-added services to tenant companies, the activities of prospecting and attracting companies (including anchors) and seeking capital for investments.
- Tenant Companies: starting from the value proposition concept, highlighted in both S-D logic and BSC, it is indicated to approach which aspects of the park service are considered more important by tenant companies, such as the reputation of the park, the availability of value-added services, the opportunity of interaction with the university and with other companies, among others.

- Science, Technology and Innovation: reflecting one of the main motivations of a science park, it is suggested to approach items like the generation of successful innovations, intellectual property and scientific publications, among other concerns.

- Sustainable Socioeconomic Development: with reference to the regional development objectives of science and technology parks, it is suggested to approach themes such as income generation and quality jobs, attracting investment and integrated actions for sustainable development.

The hypothetical-conceptual model proposed here, with the definition of indicators to measure the aforementioned constructs, should be tested and validated with tenant companies in Brazilian science parks.

\section{Conclusions}

Science and technology parks are ventures that seek to promote regional sustainable development through innovation, coordinating the resources of several strategic actors involved in these initiatives. The integration of these resources is complex and the success of this ecosystem depends on a number of factors such as the presence of a strong scientific and technological base, entrepreneurial culture, public and private resources, anchor companies, networking, real estate development and production chains, among others.

The movement of science and technology parks is recent in the world and especially in Brazil, where the most significant growth ventures occurred only from the 2000s. Nevertheless, the challenges and opportunities that arise for these ecosystems are global. Currently, for example, begins the discussion of the Areas of Innovation concept, in which science and technology parks operate more holistically, integrating in a more effective way to cities and their demands.

As seen throughout this work, an issue also relevant in this context is the development of a more robust management system that can be deployed and that assist the understanding of the resources integration and value cocreation in these ecosystems. Given this opportunity, it was used the S-D logic approach to the understanding of relationships and parks phenomena, as well as the BSC management tool, as a model of strategic performance management that can be adapted to the science and technology parks' context. By its turn, the General Hierarchical Model was applied due to the model's exploratory nature, being a way of dealing with the difficulty of establishing, at this time, more accurate and assertive cause and effect relationships between constructs. 
With the proposed model, it is expected to create a management tool that effectively contributes to the development of innovation ecosystems, indicating the strategic resources and the parameters considered most suitable for monitoring and improving performance. It is understood that this model may be useful for science and technology parks managers and public and private stakeholders interested in this mechanism, as it assists the clarification of priorities for the alignment and focus of the players in the Triple Helix and criteria for the conduct of public investment, for example.

The choice of tenant companies as focal actors of the model is justified by the fact that they are the responsible for the integration of resources provided by the ecosystem and at the same time the production/catalyzing results as increase in the number of patents, technology transfer, creation of goods and high value-added services and generation of employment and income opportunities. In this sense, the model emphasizes the resources involved in the value perception of tenant companies, as well as the value proposition of these in the form of scientific, technological and socioeconomic benefits. For future studies, it is suggested to carry out a $360^{\circ}$ empirical evaluation involving the other players in the Triple Helix (Science, Technology and Innovation Institutes and Government) in order to raise their expectations and value propositions in relation to the Science and Technology Park mechanism.

Finally, considering that the S-D logic provides a promising new theoretical framework for the analysis of science parks ecosystem, an attempt was made to demonstrate the feasibility of the development and validation of a performance management model for these ventures, based on the Service-Dominant Logic and the Balanced Scorecard. It is expected therefore that this research can open ways for new studies to discuss the identification and integration of strategic resources that will enhance the success of these ventures.

\section{References}

Andreevna, M. A. (2013). The Balanced Scorecard for estimation of science and technology parks. World Applied Sciences Journal, 25(5), 720-727.

ANPROTEC. (2015). Available at: <http://www.anprotec.org.br>. Accessed on: 28 set. 2015.

Bakouros, Y. L., Mardas, D. C., \& Varsakelis, N. C. (2002). Science park, a high tech fantasy?:An analysis of the Science parks of Greece. Technovation, 22(2), 123-128.

Bardin, L. (2000). Análise de conteúdo. Lisboa: Edições 70.

Bettencourt, L. A., Lusch, R. L., \& Vargo, S. L. (2014). A service lens on value creation: marketing's role in achieving strategic advantage. California Management Review, 57(1), 44-66.

Bigliardi, B., Dormio, A. I., Nosella, A., \& Petroni, G. (2006). Assessing science parks' performances: directions from selected Italian case studies. Technovation, 26(4), 489-505.
Dabrowska, J. Measuring the success of science parks: performance monitoring and evaluation. XXVIII IASP World Conference on Science and Technology Parks, Copenhague, 2011. 1-23.

Etzkowitz, H.; Leydesdorff, L. (1999). The future location of research and technology transfer. Journal of Technology Transfer, 24, p. 111-123.

Fernandes, S. C. R. (2014). Avaliação de Parques Tecnológicos: uma proposta de modelo para parques de $3^{a}$ geração. (Dissertação). Instituto COPPEAD de Administração, Universidade Federal do Rio de Janeiro, Rio de Janeiro.

Fiates, J. E. A. (2014). Influência dos Ecossistemas de Empreendedorismo Inovador na Indústria de Venture Capital: Estratégias de apoio às Empresas inovadoras (Tese). Programa de Pós-Graduação em Engenharia e Gestão do Conhecimento, Universidade Federal de Santa Catarina, Florianópolis.

Fukugawa, N. (2006). Science parks in Japan and their value-added contributions to new technology-based firms. International Journal of Industrial Organization, 24, 381-400.

Fundação CERTI. (2013). Compilação das Dinâmicas do Workshop ANPROTEC. (Relatório). Recife: ANPROTEC.

Gil, A. C. (2006). Métodos e Técnicas de Pesquisa Social. 5. ed. São Paulo: Atlas.

Giugliani, E., Selig, P. M., \& Santos, N. (2012). Modelo de governança para parques científicos e tecnológicos no Brasil. Brasília: Anprotec/ Sebrae.

Kaplan, R., \& Norton, D. (1997). A estratégia em ação: Balanced Scorecard. 18. ed. Rio de Janeiro: Elsevier.

Kaplan, R., \& Norton, D. (2000). Organização orientada para estratégia: como as empresas que adotam o Balanced Scorecard prosperam no novo ambiente de negócios. 8. ed. Rio de Janeiro: Elsevier.

Kaplan, R., \& Norton, D. (2004). Mapas estratégicos - Balanced Scorecard: convertendo ativos intangíveis em resultados tangíveis 9. ed. Rio de Janeiro: Elsevier.

Link, A. N., \& Scott, J. T. (2003). U. S. science parks: the diffusion of an innovation and its effects on the academic missions of universities. International Journal of Industrial Organization, 21, 1323-1356.

Lusch, R. F., \& Vargo, S. L. (eds) (2006). The Service-Dominant Logic of Marketing: Dialog, Debate, and Directions. Armonk, NY: M.E. Sharpe.

Lusch, R. L., \& Vargo, S. L. (2014). Service-Dominant Logic: premises, perspectives, possibilities. New York: Cambridge University Press.

Maglio, P. P., \& Spohrer, J. (2008). Fundamentals of service science. Journal of the Academy Marketing Science, 36, 18-20. 
MCTI. (2013). Estudo de Projetos de Alta Complexidade: Indicadores de Parques Tecnológicos. (Relatório). Brasília: CDT/UnB.

MCTI. (2015). Propostas de Políticas Públicas para Parques Tecnológicos e Incubadoras de Empresas. (Estudo). Brasília: MCTI.

Monck, C.; Peters, K. Science parks as an instrument of regional competitiveness: measuring success and impact. XXVI IASP World Conference on Science and Technology Parks, Malaga, 2009. 1-19.

Mowen, J. C., \& Voss, K. E. (2008). On Building Better Construct Measures: Implications of a General Hierarchical Model. Psychology \& Marketing, 25(6), 485-505.

Peters, L. D., Löbler, H., Brodie, R. J., Breidbach, C. F., Hollebeek, L. D., Smith, S. D., ... Varey, R. J. (2014). Theorizing about resource integration through service-dominant logic. Marketing Theory, 14(3), 249-268. http://doi.org/10.1177/1470593114534341

Phan, P. H., Siegel, D. S., \& Wright, M. (2005). Science parks and incubators: observations, synthesis and future research. Journalof Business Venturing, 20, 165-182.

Phillimore, J. (1999). Beyond the linear vies of innovation in science park evaluation: an analysis of Western Australian Technology Park. Technovation, 19, 673-680.

Rodeiro-Pazos, D., \& Calvo-Babio, N. (2012). El rol de los parques científico-tecnológicos em el empreendimento universitario: propuesta de um catálogo de indicadores de evaluación. Globalización, Competitividad Y Governabilidad, 6(2).

Sale, J. E. M., Lohfeld, L. H., \& Brazil, K. (2002). Revisiting the quantitative-qualitative debate: implications for mixed-methods research. Quality \& Quantity, 36, 43-53.
Siegel, D. S., Westhead, P., \& Wright, M. (2003). Assessing the impact of university science parks on research productivity: exploratory firm-level evidence from the United Kingdom. International Journal of Industrial Organization, 21, 1357-1369.

Squicciarini, M. (2008). Science Parks' tenants versus out-of-Park firms: who innovates more? A duration model. Journal of Technology Transfer, 33, 45-71.

Vargo, S. L., \& Lusch, R. F. (2004). Evolving to a New Dominant Logic for Marketing. Journal of Marketing: January 2004, Vol. 68, No. 1, pp. 1-17.

Vargo, S. L., Lusch, R. F. (2016). Institutions and axioms: an extension and update of service-dominant logic. Journal of the Academy of Marketing Science. 44: 5-23. doi: 10.1007/s11747-015-0456-3.

Vedovello, C. A., Judice, V. M. M., \& Maculan, A. D. (2006). Revisão crítica às abordagens a parques tecnológicos: alternativas interpretativas às experiências brasileiras recentes. Revista de Administração e Inovação, 3(2), 103-118.

Vilà, P., \& Pagès, J. (2008). Science and technology parks. Creating new environments favourable to innovation. Paradigmes, (0), 141-149.

Wieland, H., Polese, F., Vargo, S. L., \& Lusch, R. L. (2012). Toward a Service (Eco)Systems Perpective on value creation. International Journal of Service Science, Management, Engineering and Technology, 3(3), 12-25.

Yin, R. K. (2005). Estudo de caso: planejamento e métodos. 3. ed. Porto Alegre: Bookman. 